\title{
A színész mint szimulált páciens az oktatásban a Pécsi Tudományegyetemen
}

\author{
Koppán Ágnes dr. ${ }^{1}$ - Eklicsné dr. Lepenye Katalin ${ }^{1}$ \\ Halász Renáta ${ }^{1}$. Sebők Judit dr. ${ }^{2}$ - Szemán Eszter dr. ${ }^{3}$ \\ Németh Zsuzsanna dr. ${ }^{4}$. Rendeki Szilárd dr. ${ }^{4}$
}

\begin{abstract}
Pécsi Tudományegyetem, ${ }^{1}$ Általános Orvostudományi Kar, Egészségügyi Nyelvi és Kommunikációs Intézet, ${ }^{2}$ Klinikai Központ, II. Sz. Belgyógyászati Klinika, ${ }^{3}$ Klinikai Központ, Pszichiátriai és Pszichoterápiás Klinika, ${ }^{4}$ MediSkillsLab Szimulációs Oktatási Központ, Pécs
\end{abstract}

\begin{abstract}
Bevezetés: A XXI. századi orvosképzés kihívásaira adott egyik válasz a szimulációs oktatás, amely hozzájárul az orvostanhallgatók klinikai készségeinek hatékony fejlesztéséhez, csökkentve a klinikusok és a kórházi betegek terheit. Célkitüzés: A Pécsi Tudományegyetem Általános Orvostudományi Karán létrehoztunk egy szimulációs oktatási programot a MediSkillsLab intézményén belül, ahol célul tüztük ki az orvostanhallgatók anamnézisfelvételi és szakmai kommunikációs készségeinek interdiszciplináris formában történő hatékony fejlesztését.

Módszer: A kurzust a korábbi évek magyar orvosi szaknyelvi oktatása során szerzett tapasztalataink mellett nemzetközi példák felhasználásával hívtuk életre. Módszerül az Amerikában már az 1960-as években elterjedt Standardized Patient Programot választottuk.

Eredmények: Az újdonság egyrészt a program hazai, elsőkénti bevezetésében, másrészt interdiszciplinárissá tételében rejlik. Az órákon szakorvosok, nyelvészek, színész-páciensek és orvostanhallgatók együttmúködésével fejlődik a hallgatók szakmai, szaknyelvi és kommunikációs kompetenciája.

Következtetés: A kurzust teljesítő diákokkal készített interjúk megerősítik a módszer létjogosultságát, amelynek eredményeként a betegekkel eredményesebben kommunikáló orvosok kezdhetik meg klinikai munkájukat.

Orv Hetil. 2017; 158(26): 1022-1027.
\end{abstract}

Kulcsszavak: szimulációs oktatás, MediSkillsLab, interdiszciplináris kurzus, anamnézisfelvétel színészekkel, szakmai és szaknyelvi kompetencia, orvos-beteg kommunikáció

\section{Actor as a simulated patient in medical education at the University of Pécs}

Introduction: Medical training in the 21 st century faces simulation-based education as one of the challenges that efficiently contributes to clinical skills development while moderating the burden on the clinicians and patients alike. Aim: The University of Pécs, Medical School has launched a simulation program in the MediSkillsLab based on history taking with actors to improve patient interviewing communication skills.

Method: This new program was inspired by experiences gathered in previous medical language teaching and integrates the method of the "Standardized Patient Program". The method has been applied in America since the 1960s. Results: This is the first time the program has been introduced in Hungary and implemented in an interdisciplinary design, where medical specialists, linguists, actor-patients and medical students collaborate to improve professional, language and communicative competence of the students.

Conclusion: A course like this has its pivotal role in the medical training, and as a result more efficient and patientoriented communication may take place at the clinical setting.

Keywords: simulation-based education, MediSkillsLab, interdisciplinary course, history taking with patients, professional and language for specific purposes competencies

Koppán Á, E Lepenye K, Halász R, Sebők J, Szemán E, Németh Zs, Rendeki Sz. [Actor as simulated patient in medical education at the University of Pécs]. Orv Hetil. 2017; 158(26): 1022-1027. 
A szimuláció mint technika mind az oktatásban, mind pedig a készségek felmérésében már az 1900-as évek elejétől használt volt, kezdetben az aeronautikában és a hadászatban [1]. A szimulációs technika egészségügyi oktatásba való transzlációja az elmúlt évtizedekben csaknem exponenciális növekedést eredményezett a szimuláció mint eszköz felhasználásában. A szimuláció valódi páciensek, anatómiai régiók, klinikai feladatok replikációját, valamint élethű helyzetek klinikai összefüggésben való megjelenítését célozza meg [2]. A szimuláció világszerte megnövekedett alkalmazását az egészségügyi oktatásban számos körülmény serkentette. Egyrészt a nehéz vagy ritka klinikai helyzetek gyakorlására nyílt általa lehetőség a készségfelmérésben, másrészt általános tendenciává vált a páciens és a képzés alatt álló személyzet klinikai helyzetekben való találkozásának egyre szűkülő volta, ami a képzést jelentősen hátráltatta. Mindezt a klinikai oktatásban részt vevők oktatásra fordítható idejének csökkenése magyarázta, valamint az egyre modernebb diagnosztikus és kezelési modalitások megjelenése miatt az orvos és páciense közötti „távolodás” éppúgy, mint a páciens biztonságára és személyes jogaira fektetett egyre nagyobb hangsúly [2-6]. Mindezzel összefüggésben, az egészségügy területén az oktatásban dolgozók sikeresen adoptáltak számos életképes módszert a klinikai és nem klinikai szituációk széles körének oktatására. A szimulációs technikák magukban foglalják a standardizált, illetve szimulált páciens (SP), az anatómiai modellek, különböző részfeladat-gyakorlók (például Pelvi-tréner), számítógéppel vezérelt humán páciensszimulátor-modellek, valamint a virtuális valóság mai szintjén megjeleníthető, szinte végtelen lehetőségek tárházát kínáló módszereiket is $[1,2]$. Míg a standardizált páciens alatt olyan létező személyt értünk, akit valós anamnesztikus adatai vagy fizikális vizsgálati leletei alapján az orvosi oktatásban alkalmazunk, addig a szimulált páciens olyan, valódi eltérés nélküli személy, aki egy pácienst különböző szintû tréningek során szerzett ismeretanyag birtokában szimulálni képes [7].

Ezek a technikák különösen a végzés előtti időszakban jelentenek óriási lehetőséget a hallgatóknak, mielőtt jogosítványt szereznének a páciensekkel való teljes mértékű szakmai kontaktusra; mindezt úgy teszik, hogy maximális tanulási lehetőséget kínálnak, ugyanakkor a mindenkori páciens biztonságát nem veszélyeztetik [8$10]$.

A szimuláció biztonságos környezet a gyakorlásra, ahol lehetőség van fokozatosan emelkedő nehézségi szintek beépítésére, amelyek a gyakorló felkészültségi szintjéhez alkalmazkodva kerülnek alkalmazásra. Mindezt annak fényében kell szemlélnünk, hogy a valódi pácienseken való gyakorlás nehéz, költséges, potenciálisan veszélyes és etikátlan, valamint egyre kevésbé elérhető volta mindenki számára nyilvánvaló $[2,3,5,6]$.

A modern kori orvosképzésben Barrows és Abrabamson fundamentális munkája nyomán indult meg a stan- dardizált páciensre alapuló képzési formák mind szélesebb körben való elfogadása [11].

Kezdetben az SP-k alkalmazása pedagógiai célzattal történt, és legfóbb célja feed-back szolgáltatása volt az orvostanhallgatók számára. Hamarosan új célként jelent meg a módszerben rejlő, egy jóval értékesebb tulajdonság kiaknázása is, mégpedig a hallgatók standardizált oktatása élethű körülmények között [12]. Az utóbbi két évtizedben már általánossá vált a módszernek licenct adó vizsgáztatási formákban való használata is [13, 14]. Ugyanakkor az orvosképzés szereplői az Egyesült Államokban már a késő 1980-as és kora 1990-es években komoly aggodalmat fogalmaztak meg annak felismerése kapcsán, hogy bár a technikai fejlődés adta vívmányok az orvosképzésben és orvoslásban korábban el nem képzelhető mértékben kerültek alkalmazásra, a legalapvetőbb orvosi készségek nem megfelelő kifejlesztése vagy időközbeni elvesztése az egészségügy általános megítélésében tapasztalható elégedetlenséghez vezetett. Ez különös mértékben nyilvánult meg az orvos-beteg interakciókkal kapcsolatos egyre növekvő társadalmi kritikákban [15]. „Az orvostudomány olyan múvészet, amelynek varázsa és kreatív ereje már régóta elfogadott tényként az orvos-páciens kapcsolat interperszonális aspektusaiban nyugszik" - írta korabeli tanulmányában Hall [16]. Egy klinikus szakmai karrierje során hozzávetőleg 100 000200000 anamnézisfelvételt készít el [17]. Ezek alapján könnyedén belátható tehát, milyen fontos az egészségügyi személyzet és a páciens közötti kommunikáció megfelelő vezetése, és a graduális és posztgraduális képzés során ennek szakemberek általi oktatása a jövő nemzedéke számára.

\section{Célkitüzés}

A Pécsi Tudományegyetem Általános Orvostudományi Karán 2016-ban a magyar és a német programon „Anamnézisfelvétel színész-páciensekkel - szimulációs gyakorlatok a MediSkillsLab-ben" - címú kurzust indítottuk el, amellyel egyrészt hatékonyabbá kívánjuk tenni az anamnézisfelvételhez szükséges kompetenciák fejlesztését, másrészt azt kívánjuk bizonyítani, hogy a hallgatók szaknyelvi kommunikációs készsége jelentősebb mértékben fejlődik a színész-páciensekkel gyakorolva, mint a korábbi, hagyományos módszereket alkalmazó kurzusok során.

\section{Módszer}

A kurzus során, valamint a releváns oktatási anyag fejlesztésében, az oktató szakorvosok együttmúködnek a nyelvész-kommunikációs szakemberekkel. A klinikusok által kiválasztott klinikai esetek alapján betegprofilok kidolgozása történik. Ezeket a betegprofilokat az anamnézis múfajának, szövegszerkezetre vonatkozó kritériumainak figyelembevételével dolgozzuk fel, majd „szere- 
pekként" nyújtjuk át a Pécsi Nemzeti Színház színészeinek megtanulásra.

A színészek által megformált, szakmailag hiteles betegprofilok bemutatása releváns klinikai esetek szimulációjaként történik, klinikusok és nyelvész szakemberek által kontrolállt, moderált és narrált módon.

A különböző betegprofilok és karakterek kidolgozását többéves előkészítő munka előzte meg. A szimulált páciens oktatási modell alapjaként az orvoskaron már évek óta múködő „TANDEM - Anamnéziscsoport” oktatási projekt szolgált, amelyben német és magyar programon tanuló hallgatók és felsőbb évfolyamos tutorok vesznek részt. Ezeknek az anamnéziscsoportoknak az eredeti célja a betegkikérdezési technikák kölcsönös fejlesztése, külföldi és magyar hallgatók egymást segítve tanulásának előmozdítása volt. Ezen alapulva az úgynevezett „Peer learning, peer tutoring" speciális, kétnyelvű modelljét dolgoztuk ki hallgatóink hatékonyabb oktatására [18]. Ezen oktatási modell alkalmazása során összegyúlt nagyszámú, magyar és német nyelvú betegprofil szolgált a későbbiekben az orvoskarunkon megteremtett szimuláltpáciens-módszer kiindulási pontjául.

\section{A színészek felkészítése}

Színészeink a Pécsi Nemzeti Színház és a Szekszárdi Német Színház (Deutsche Bühne) múvészei. Felkészítésük első fázisa a szerepmegismerés. Ezen fázis során a színész autentikus, klinikai környezetben részletesen megismeri az adott szerep alapjául szolgáló klinikai esetet, illetve eseteket: az erre önként vállalkozó pácienssel vagy páciensekkel folytatott anamnézisbeszélgetésnek a színész passzív megfigyelóje. A szerepet betanító klinikus által vezetett anamnézisfelvétel során minden részletre kiterjedő esetfeldolgozás valósul meg. A színész ebben a fázisban ismeri meg az adott klinikai képhez logikailag rendelhető összes releváns kérdést, illetve az azokra adható válaszokat. Továbbá felfedezi az adott kórképre jellemző viselkedésmintázatokat (például szorongás, fájdalom miatti mozgáskorlátozottság stb.). Ez tehát egy passzív megfigyelói folyamat.

Ezt követi a színészek aktív esetértelmezése a klinikussal és a nyelvész kollégával. Ebben a második fázisban történik meg a páciens általános hogylétét, pszichoszomatikai állapotát, tünettanát jól tükröző szerep megformálásához elengedhetetlen „kellékek”, az adott betegségre jellemző elváltozások, klinikai jegyek, jellemző panaszok és viselkedésmintázatok betanítása. A szakembertôl megtanulja a színész a tünettan markáns jegyeit, illetve a vonatkozó diagnosztikai lépések, mint például laboratóriumi vizsgálathoz mintavétel (vér, vizelet, széklet stb.) vagy múszeres diagnosztika (például mellkasröntgen vagy koponya-CT-felvétel) menetét, valamint alapvető terápiás következmények (gyógyszeres vagy mútéti kezelés) várható voltát is. Ez tehát egy interaktív tanulási folyamat.
A harmadik fázisban történik a szimulált eset megformálása. Ez az előzőekben megtanult, adott klinikai eseten vagy eseteken alapuló fiktív eset megalkotását jelenti. Ebben a folyamatban a nyelvész/kommunikációs szakember az adott eset minimálisan elvárható kommunikációs, nyelvi bázisának (akár magyar, akár idegen nyelvú) és az adott klinikai eset szakmai keretének harmonizálásával, azaz a nyelvileg és szakmailag is elvárható ismeretek garantált egybeépítésével alakítja a szerepet. A kialakított szerep betanítása/betanulása elő́tt a klinikus ellenőrzi a szakmai helyességet. Ugyanakkor ebben a fázisban a betegprofilhoz egy komplett élettörténet is hozzáíródik (a valóságon alapulva). Ennek fontossága abban rejlik, hogy a családi és a szociális kerettörténet által maga a betegtörténet is kerek egésszé válik, ami által a színész is bele tudja helyezni magát az eljátszani kívánt ember életébe. Ezzel párhuzamosan zajlik a szimulált páciens személyiségének kialakítása is, hiszen a színészek számára csak így válik szereppé a betegprofil, amellyel azonosulhat: egy ember történetévé és karakterévé, amely megformálható és eljátszható. Ezen folyamat szakmai hitelességének záloga a program résztvevőjeként tevékenykedő pszichiáter általi folyamatos kontroll. Tevékenysége kiterjed arra is, hogy ellenőrizze, milyen állapotú jelenleg a szimulált beteg, mennyire kikérdezhető, mindezen túl milyen karakterú a személyisége, kooperáló alkat-e vagy nem, nyitott, beszédes-e, esetleg túlzottan zárkózott, nehezen megnyíló vagy akár agresszív tulajdonságokkal bír-e. Amennyiben az utóbbi tulajdonságok valamelyike kerül megformázásra, a szakember irányítása alatt feltárhatóvá válik a karakter mögött meghúzódó esetleges alkohol- vagy drogfüggőoség, illetve depresszív okok is. Ezen beépíthetô modulok által körvonalazható tehát a különböző pácienskaraktereknek az orvoshoz, illetve az anamnézist felvenni kívánó személyhez való hozzáállása [19]. Mindezen karakterek megformálásával a szokványos orvos-beteg kommunikáció teherbíró képességét meghaladó esetek is beépítésre kerülnek az oktatási programba. A vázolt lépések által elkészített sokféle betegprofilt tanulják meg a színészek.

A negyedik fázisban a színész - éppen úgy, mint a színházban - felkészül a szerepre, azaz megtanulja, magáévá teszi azt.

A fenti módon létrehozott, írásos, valamint az alábbiakban még részletezett különböző médiaformátumban is archivált fiktív eseteken alapuló „tananyagbank” folyamatosan bővül, de a fiktív esetek alapjául mindenkor a klinikus kollégák által megadott konkrét klinikai esetek szolgálnak. Jelenleg a Pécsi Tudományegyetem szimulált páciens oktatási projektjében a következő szakterületekhez tartozó megformált esetek állnak az oktatás rendelkezésére: belgyógyászat, kardiológia, nefrológia, gasztroenterológia, sürgősségi orvostan, neurológia, nőgyógyászat. Az adott szakterülethez tartozó, az oktatás számára elérhető szimulált esetek mindenkori száma természetesen a klinikus kollégák igényeinek megfelelően emelkedik. 


\section{A szimulációs gyakorlat}

A fentiekben részletezett módon megformált szimulált eset kerül „bemutatásra” arra alkalmas „színtéren”. A gyakorlatok a klinikai szituációra mindenben hasonlító fizikai körülmények között, a PTE ÁOK MediSkillsLab termeiben zajlanak. A MediSkillsLab munkatársai betegágy és vizsgálóasztal, valamint egyéb, nélkülözhetetlen orvosi kellékek beszerzésével élethú helyszínt rendeznek be a tanulócsoportok számára. A gyakorlat során lehetőség van arra, hogy a hallgatók kisebb csoportokban vagy önállóan folytassanak le beszélgetést a színész-pácienssel, amelyet egy „observerteremból” a csoport többi tagja a szakmai vezetőkkel együtt megfigyelhet és közösen kiértékelhet.

A gyakorlat három fontos egységre tagolható. Az első a csoportokban vagy egyénileg történő anamnézisfelvétel, más néven strukturált betegkikérdezés. Ezt követi a referálás, amikor a csoport egy tagja a megadott idókeret végén az addig összegyújtött információ alapján a gyakorlatvezető klinikusnak referál. Ezután következik a kiértékelés, amely három fó szempont szerint történhet: 1 . szakmai szempontból (a jelen lévő klinikus által), 2. nyelvészeti és kommunikációs szempontból (a nyelvész kollégák által), 3. a páciens szempontjából (az ôt alakító színész által). Utóbbi a strukturált feed-back adását és fogadását is lehetővé teszi. Mivel a gyakorlatok zárt csoportokban zajlanak, lehetôség van arra is, hogy a hallgatók maguk is megfigyeljék a beszélgetést, majd ezt követően ők is feed-backet adjanak. Minden órán kettő vagy három különböző szcenárió feldolgozására kerül sor.

A színész-páciensekkel folytatott anamnézisfelvételi beszélgetéseket rögzítik. Így tehát nyomon követhető, hogy a kurzus résztvevői a félév folyamán hogyan fejlődnek, mennyire tudják fejleszteni nyelvi és kommunikációs készségeiket. A felvételek alapján ugyanis a beszélgetésekről transzkripciók készülnek, amelyek lehetővé teszik a beszélgetések többféle szempontú kiértékelését: a szakmai mellett nyelvi és kommunikációs aspektusok alapján is.

\section{Megbeszélés}

Jelen közleményünkben a színész-páciensek mind magyar, mind a magyarországi idegen nyelvű orvosképzésben való alkalmazásának első hazai bevezetéséról számolunk be. Az orvosi kommunikáció, mindenekelőtt az anamnézisfelvétel, egyike a legfontosabb és leggyakoribb orvosi feladatoknak. Egy 2015-ös tanulmány arra a következtetésre jutott, hogy a korai preklinikai tanulmányaikat folytató hallgatók jelentősen profitálhatnak olyan oktatási helyzetekből, ahol elsősorban betegkikérdezési készségeiket fejlesztik ahelyett, hogy figyelmüket különböző differenciáldiagnosztikai problémák vagy a klinikai menedzselés irányába terelnék [17].

Történelmileg az orvosképzés egyik központi eleme a valós beteget kezelő klinikus általi megfigyelés, valamint a pácienssel történő együttmúködés. Ezt a nélkülözhetetlen feladatot ma már szimulációs betegek bevonásával is elvégezhetik az orvostanhallgatók, amely tanulási folyamat során kontrollált körülmények között egyúttal életszerú tapasztalatot is szerezve fejleszthetik készségeiket.

A kurzus során alkalmazott módszer a Standardized Patient Program módszere, amely szimulációs betegkikérdezésre és betegvizsgálatra épül [11,20]. Tanulmányok sora bizonyítja, hogy e módszer segítségével mind a kommunikatív, mind pedig a gyakorlati készségek alaposan és mélyrehatóan elsajátíthatóak [21-24].

Az Egyesült Államokban az 1960-as évek óta alkalmaznak színész-pácienseket [11, 25, 26]. Először olyan speciális technikák gyakoroltatására képeztek ki színészeket, mint a neurológiai betegvizsgálat [11]. Később speciális szituációkat, úgymint rossz hír közlését vagy felvilágosító beszélgetések vezetését tanulhatták meg a hallgatók színész-pácienseken. Ezt követte a színész-páciensekkel történő további beszélgetésvezetési technikák megtanulása, mint a teljes anamnézisfelvétel vagy a fizikális betegvizsgálat elsajátítása. Olyan híres amerikai orvosképző centrumokban múködnek ilyen képzési programok, mint a Chicagói Egyetemen a „Clinical Performance Center”-ben vagy a "Morchand Center for Clinical Competence"-ben a Mount Sinai School of Medicine-en, New Yorkban. Ezek a központok az Egyesült Államokban már évtizedek óta koordinálják a színész-páciensek képzését és az oktatásban való alkalmazásukat is. A program Németországban szintén elterjedt: neves egyetemeken elérhető az oktatásban, mint például a berlini Charitén vagy a Giesseni Egyetem Orvosi Karán. A Charitén 1999 óta mintegy 130 standardizált páciens vesz részt az oktatásban, egyharmaduk színész, és évente mintegy $\mathbf{5 5 0 0}$ alkalommal zajlik színész-páciens és orvostanhallgató közötti tréning [27].

Ugyanakkor Magyarországon egyelöre korántsem ilyen előrehaladott az orvosképzés módszertana, mint az említett országokban. Mind ez idáig egyetlen képzési centrumban sem került ennek a módszernek a bevezetése a graduális és posztgraduális képzés curriculumába. Pedig Buda Béla már 1986-ben sürgette a kommunikációs készségek fejlesztését, az empátia fokozását az egyetemi orvosképzés során, amelynek elengedhetetlen feltétele a nem verbális kommunikáció fóbb csatornáinak, egyetemes és biológiai kódjainak ismerete, megértése, észlelése [28]. Sốt Szili munkásságának eredményeként azt is elmondhatjuk, hogy a módszer révén lehetôség nyílik a „nehéz” páciensekkel való bánásmód gyakorlására is, a velük alkalmazott udvariassági stratégiák tudatos megválasztására, ezáltal pontosabb anamnézis felvételére és szorosabb kooperációra a terápia sikeres véghezvitelét illetően [29]. A Pécsett megvalósult program tehát évtizedes lemaradásunkat hivatott pótolni a területen. Ugyanakkor hangsúlyozzuk, hogy az itt részletezett módszer a meglévő, betegágy melletti oktatás kiegészítésére és nem annak pótlására került bevezetésre, meggyő- 
ződésünk ugyanis, hogy a valódi betegekkel való találkozás sosem lesz nélkülözhető az orvosképzés módszertanában.

Az ma már szakmai közhely, hogy ha a színész-páciens megfelelő képzésben részesül, alig megkülönböztethető az igazi pácienstől [30]. Alkalmazásuk előnye az amatőr programozott páciensek alkalmazásával szemben nyilvánvaló. A profi színészek tanult mesterségüknél fogva ugyanis még inkább képesek a valósághü betegkarakterek és szituációk megjelenítésére. A pécsi modell éppen ezért kezdeményezte a világon még nem mindenütt elterjedt színész-páciens alkalmazását a szimulált beteg oktatási programban. A professzionális színészek alkalmazásának előnye különösen igaz a mélyebb problémákat magukban hordozó helyzetek, például valamilyen abúzussal vagy pszichés problémával küzdő betegek, de éppúgy drámai helyzetek megformálása során is. Hallgatóink beszámolói és feed-backjei is arról tanúskodnak, hogy esetünkben a Pécsi Nemzeti Színház mưvészei képesek voltak szinte teljesen elfeledtetni velük, hogy valójában szimulációról van szó. A módszer alkalmazásának éppen az az előnye, hogy a színész-páciensek reakciói és emóciói spontán jelentkeztek, éppen úgy, mintha valós klinikai helyzetben lettek volna, ezért a hallgatókban létrejövő késztetés a feladattal való megbirkózásra ugyanolyan valóságos volt. Nehézsége ugyanakkor a módszernek, hogy a betegprofilok kialakítása egy igen összetett feladat, hiszen minden beteg más, ráadásul igen összetett a különböző karakterek orvos-páciens helyzetben való megjelenése. Ennek megfelelően a valósághű bemutatás jegyében a hallgatók számára is éppen annyira összetettnek kell lennie a feladatnak, mint amilyennel a valóságban találkozhatnak. Ezért kellő számú betegprofilt tartalmazó szimulációs bank létrehozása szükséges, ami igen időigényes feladat. Azonban a már megalkotott profilok archiválásával hosszú távú tananyagbázis hozható létre.

Módszerünk további előnye, amely egyben újdonság is, klinikai pszichiáter jelenléte a kurzusok során, sőt már a kurzusanyagok, betegprofilok kidolgozásában, megformálásában is. Ennek előnye abban mutatkozik meg, hogy a hallgatók ezekben a szituációkban - válaszul a professzionális színész-páciensek viselkedése, reakciói által generált mindenkori atmoszférára - szintén valós reakciókat produkálnak, éppen olyat, mintha a valós pácienssel élnék meg az interjút vagy az adott szituációt. Ebből kifolyólag a saját problémamegoldó készségeik fejlesztése - mint például kellemetlen, kínos helyzetek kezelése, rossz hír közlése, a páciens válaszai, viselkedése által bennük kialakult reakciók (esetleges döbbenet, együttérzés stb.) -, megfelelő kezelése szakember irányítása mellett történik, tehát az egészségügyre jellemző speciális interperszonális helyzetek adta konfliktusok megoldására készségük adekvátan fejleszthető.

Mivel minden alkalommal jelen van az adott szimulált helyzet orvosi szakterületét képviselő szakorvos vagy szakorvosjelölt (belgyógyász, oxiológus, pszichiáter, nő- gyógyász stb.), a szaknyelvi kommunikatív kompetenciafejlesztés mellett szakmai készségfejlesztés is történik.

Szintén kiemelendő a jelen közleményben bemutatott módszer adta lehetőségek között az orvos-beteg kommunikáción túl olyan területekre vonatkozó készségfejlesztés is, mint az orvos-hozzátartozó és az orvos-orvos közötti, illetve általánosságban az egészségügyi teamen belüli kommunikáció. A színészek alkalmazása napjaink ezen orvosszakmai kommunikációs kihívásainak megfelelő oktatásra, akár több résztvevős szituációk szimulálására is lehetőséget nyújt (élethú, összetett konfliktusos jelenetek megformálása: például orvos-beteg-hozzátartozó).

A professzionális színészek alkalmazása lehetővé teszi ezeknek a szituációknak akár azonnali megismétlését. Lehetőség van a beszélgetés csak bizonyos részeinek megismétlésére, kielemzés után ismételt lebonyolítására is.

Ezeken túlmenően a szimulált szituációk alkalmazásának előnye a technikai környezet adta reprodukálhatóság, valamint a késleltetett, választott időpontban zajló, egyedi vagy csoportszintü analízis lehetősége is. A kurzusokról ugyanis a MediSkillsLab-ben rejtett kamerás felvételek készíthetők, amelyek a foglalkozás intimitását, a szakmai vonalvezetést nem zavarják. A felvételek ezt követően az érintettek részvételével kiértékelhetőek, valamint archivált anyagként az oktatásban később felhasználhatóak.

Módszerünk mind a magyar, mind az idegen nyelvű program oktatásában alkalmazható: egyrészt magyar szimulációs páciensekkel, amely készségre a magyar hallgatókon kívül a klinikai tanulmányaikat Magyarországon végző minden külföldi hallgatónak is szüksége van. Másrészt karunk feladata az is, hogy a külföldi hallgatókat felkészítse arra, hogy visszatérve anyaországukba, németül vagy angolul, illetve saját anyanyelvükön képesek legyenek megfelelő szakmai kommunikációra. Betegprofiljaink ezért készülnek három nyelven, a szituációk pedig német nyelven a szekszárdi Deutsche Bühne német színészei segítségével, magyar nyelven pedig a Pécsi Nemzeti Színház színészei által már kipróbálásra kerültek. Az angol nyelvü színészek felkészítése előkészületi fázisban jár.

Ugyanakkor hangsúlyozni szeretnénk, hogy a színészpáciensek orvostanhallgatók képzésében való alkalmazása a valódi páciensekkel történő oktatást semmiképpen nem helyettesíti, csak kiegészítheti azt.

A színész/szimulációs páciensek alkalmazása a fentieken túl a szakmai képzés területén is felhasználható. A jövőben tervezzük a módszer bevonását a különböző klinikai tantárgyak moduljaiba, hiszen a növekvő hallgatószámmal megterhelt klinikai oktatást tehermentesítheti, ha egy-egy tantárgyi óra színész-páciensek bevonásával zajlik. Az ilyen oktatást végző centrumban rendelkezésre álló számos szimulációs eszköz pedig a tanóra szimulált betegvizsgálattal történő kiegészítését, azaz a komplex szimulációt is lehetővé teszi. 
Anyagi támogatás: A közlemény megírása anyagi támogatásban nem részesült.

Szerzôi munkamegosztás: Valamennyi szerző hozzájárult a kézirat mögött álló munkahipotézis kollektív megalkotásához, illetve a módszer adoptálásához, részt vett a módszer irodalmi hátterének áttekintésében, valamint a kézirat jelen formában történő megírásában. A cikk végleges változatát valamennyi szerző elolvasta és jóváhagyta.

Érdekeltségek: A szerzóknek nincsenek érdekeltségeik.

\section{Irodalom}

[1] Rosen KR. The history of medical simulation. J Crit Care 2008 23: 157-166.

[2] Issenberg SB, Scalese RJ. Simulation in health care education. Perspect Biol Med. 2008; 51: 31-46.

[3] Gaba DM. The future vision of simulation in health care. Qual Saf Health Care 2004; 13(Suppl 1): i2-i10.

[4] Weller JM, Nestel D, Marshall SD. Simulation in clinical teaching and learning. MJA 2012; 196: 1-5.

[5] Ziv A, Small SD, Wolpe PR. Patient safety and simulation-based medical education. Med Teach. 2000; 22: 489-495.

[6] Ziv A, Wolpe PR, Small SD, et al. Simulation-based medical education: an ethical imperative. Acad Med. 2003; 78: 783-788.

[7] Beigzadeh A, Bahmanbijari B, Sharifpoor E, et al. Standardized patients versus simulated patients in medical education: are they the same or different. J Emerg Pract Trauma 2016; 2: 25-28.

[8] Watson R, Stimpson A, Topping A, et al. Clinical competence assessment in nursing: a systematic review of the literature. J Adv Nurs. 2002; 39: 421-431.

[9] Alinier G, Hunt WB, Gordon R. Determining the value of simulation in nurse education: study design and initial results. Nurse Educ Pract. 2004; 4: 200-207.

[10] Seropian MA, Brown K, Gavilanes JS, et al. Simulation: not just a manikin. J Nurs Educ. 2004; 43: 164-169.

[11] Barrows HS, Abrahamson S. The programmed patient: A technique for appraising student performance in clinical neurology. J Med Educ. 1964; 39: 802-805.

[12] Boulet JR, De Champlain AF, McKinley DW. Setting defensible performance standards on OSCEs and standardized patient examinations. Med Teach. 2003; 25: 245-249.

[13] Grand'Maison P, Brailovsky CA, Lescop J, et al. Using standardized patients in licensing/certification examinations: comparison of two tests in Canada. Fam Med. 1997; 29: 27-32.

[14] Brailovsky CA, Grand'Maison P. Using evidence to improve evaluation: A comprehensive psychometric assessment of a SP-based OSCE licensing examination. Adv Health Sci Educ Theory Pract. 2000; 5: 207-219.
[15] Whelan GP, Boulet JR, McKinley DW, et al. Scoring standardized patient examinations: lessons learned from the development and administration of the ECFMG Clinical Skills Assessment (CSA). Med Teach. 2005; 27: 200-206.

[16] Hall JA, Roter DL, Rand CS. Communication of affect between patient and physician. J Health Soc Behav. 1981; 22: 18-30.

[17] Keifenheim KE, Teufel M, Ip J, et al. Teaching history taking to medical students: a systematic review. BMC Med Educ. 2015; 15: 159.

[18] Koppán A, Eklicsné Lepenye K, Halász R, et al. Introduction to the Pécs Model. Innovation in teaching Medical History Taking. 1st International Conference on Higher Education Advances. June 24-26, 2015, Valencia, Spain. DOI: http://dx.doi.org/ $10.4995 /$ HEAdl 5.2015 .528

[19] Cannarella Lorenzetti R, Jacques CH, Donovan C, et al. Managing difficult encounters: understanding physician, patient, and situational factors. Am Fam Physician 2013; 87: 419-425.

[20] Ladyshewsky R, Gotjamanos E. Communication skill development in health professional education: the use of standardised patients in combination with a peer assessment strategy. J Allied Health 1997; 26: 177-186.

[21] Roter D, Larson S, Shinitzky H, et al. Use of innovative video feedback technique to enhance communication skills training. Med Educ. 2004; 38: 145-157.

[22] Amodt CB, Virtue DW, Dobbie AE. Trained standardized patients can train their peers to provide well-rated, cost-effective physical exam skills to first-year medical students. Fam Med. 2006; 38: 326-329.

[23] Yedida MJ, Colleen CG, Kachur E, et al. Effect of communications training on medical student performance. JAMA 2003; 290: 1157-1165.

[24] Barrows HS. An overview of the use of standardized patients for teaching and evaluating clinical skills. Acad Med. 1993; 68: 443451.

[25] Jason H, Kagan N, Werner A, et al. New approach to teaching basic interview skills to medical students. Am J Psych. 1971; 127: 1404-1407.

[26] Werner A, Schneider JM. Teaching medical students interactional skills: A research based course in the doctor-patient relationship. N Engl J Med. 1974; 290: 1232-1237.

[27] von Fuchs C. Arztausbildung: Schauspieler mimen Patienten. Berliner Zeitung 2012 (August).

[28] Buda B. Direct human communication. [A közvetlen emberi kommunikáció.] Animula Kiadó, Budapest, 1986; pp. 187-195. [Hungarian]

[29] Szili K. Pragmatics of politeness. [Az udvariasság pragmatikája.] Magyar Nyelvốr 2007; 131: 1-17. [Hungarian]

[30] Badger LW, deGruy F, Hartman J, et al.: Stability of standardized patients' performance in a study of clinical decision making. Fam Med. 1995; 27: 126-31.

(Koppán Ágnes dr., Pécs, Szigeti út 12., 7624 e-mail: akoppan@gmail.com)

\section{"Una lectio non facit doctorem." (Egy előadás még nem avat doktorrá.)}

